\title{
ROBERT D'ARBRISSEL: UMA EXPERIÊNCIA CURIOSA DE RELACIONAMENTO ENTRE HOMENS E MULHERES NA IGREJA CRISTÃ MEDIEVAL
}

Marcos Roberto Nunes Costa

SÍNTESE - Dentre os movimentos religiosos do século XI, destaca-se o de Roberto d'Arbrissel, fundador da Ordem de Fontevraud, na qual conviviam homens e mulheres, cabendo a estas a direçāo. $O$ projeto não teve longa duração em uma igreja de celibatários misóginos, e Roberto, apesar de suas virtudes, não foi canonizado.
ABSTRACT - Among the religious movements of the eleventh century stands out the order of Fontevraud, founded by Robert of Arbrissel, in which men and women lived together. Women were the managers. The project did not last a long time in a church of unmarried mysogenous people. In spite of his virtues, Robert was not canonized.

\begin{abstract}
"Num tal momento da história, os contrastes aparecem com uma evidência extraordinária, e é então que se pode compreender melhor o que é uma civilização; é então que vêm plenamente à luz as tensões que aí se albergam" (Jacques Le Goff)
\end{abstract}

\section{Introdução}

A partir da leitura de alguns textos, andamos procurando uma maneira sintética de descrever a mentalidade da Igreja e da sociedade medieval para com o relacionamento entre homens e mulheres na Idade Média. Tarefa difícil, pois, para isto significaria ter que abordar uma gama de assuntos correlatos como: virgindade, casamento, abstinência sexual, pecados sexuais, etc., o que se adequaria mais para um tratado do que para um simples artigo.

Tentando fugir da amplitude do tema, resolvemos delimitá-lo tomando como ponto de referência a experiência de conflito existencial do padre Robert

Professor de Filosofia Medieval da Universidade Católica de Pemambuco e Mestrando em Filosofia pela Universidade Federal de Pernambuco. 
d'Arbrissel, por ocasião da regulamentação do celibato na Igreja Cristã ocidental. Esse extraordinário padre pregador que, diferente dos demais padres de sua épo$\mathrm{ca}$, adotou como martíno viver a abstinência sexual convivendo com mulheres, fundando uma ordem religiosa mista onde os homens estavam submissos às mulheres e, mais do que isto, onde as superioras (prioresas e abadessas) eram escolhidas entre as pecadoras e não entre as virgens.

Portanto, para além do que o título sugere, é nossa intenção, neste trabalho, a partir da experiência de Robert d'Arbrissel levar o leitor a entrar em contato com a mentalidade da Igreja e da sociedade medieval frente à sexualidade; as relações econômico-sociais construídas em torno deste tema e a construção de um sistema de valores morais cristãos. Nossa proposta é de natureza axiológica, onde, a partir de uma experiência concreta, possamos encontrar os valores e desvalores morais da sociedade medieval.

\section{1 - Revendo um pouco a história do celibato}

A luta pela implantação do celibato entre os padres da Igreja vinha desde os cristãos primitivos. São Paulo já optara e recomendara o celibato como forma de maior disponibilidade ao serviço de Deus (1 Cor 7,7 c 9,5), muito embora não tenha feito disto uma regra geral. Ele mesmo em Tm 3,3 e Tt 1,6 admitia a existência de padres casados: "É necessário que o epíscopo seja esposo de uma única mulher".

Nos três primeiros séculos nenhuma lei, nem no Oriente nem no Ocidente, proíbe a ordenação de homens casados, bem como o casamento após a ordenação. Só no século IV proibiu-se o casamento após a ordenação; as ordenações de casados continuaram. Do século $\mathrm{V}$ ao $\mathrm{X}$, muitas regras seriam implantadas, muitas delas de forma isolada, diferenciando-se entre o Oriente e o Ocidente, entre bispados etc., mas nunca como regra geral. Mesmo não sendo regra geral, a adesão ao celibato crescia, principalmente entre os monges. É a partir de 1074, com o papa Gregório VII, que o celibato passa a ser obrigatónio para todos os religiosos, apesar de o casamento já existente, ainda que ilícito, ser considerado; ou seja, os padres deveriam viver a abstinência, separando-se de suas esposas, mas deveriam mantêlas economicamente. A partir de 1170, o papa Alexandre III, além de tornar inválidos os casamentos já realizados, decide que a ordenação de casados só deveria acontecer se a esposa, além de dar seu consentimento, também fizesse voto de castidade. Por conseguinte, a possibilidade de ordenação de casados continuou. A proibição definitiva só viria aparecer no Código de Direito Canônico de 1917, sendo o casamento considerado impedimento ao ingresso no sacerdócio. Seria imposta definitivamente a lei do celibato.

É neste contexto, na virada do século X para o XI, que vamos encontrar a figura de Robert d'Arbrissel, um dos mais veementes defensores das reformas gregorianas, principalmente na regulamentação do casamento entre os leigos e do celibato entre os padres. 


\section{2-A luta em defesa das reformas gregorianas}

Robert d'Arbrissel nasceu por volta de 1045. Os narradores de sua história afirmam que nem ele mesmo sabia a data do seu nascimento; também não interessava, pois mais significante era a data de sua morte, dia em que retornou ao $\mathrm{Pai}$, dia de sua libertação. "O que chamamos nascer é, para espiritualidade medieval, apenas o começo de um exilio, de uma noite sempre excessivamente longa" (Dalarun, 1990: p. 13).

Robert nasceu em meio à cristandade, na pequena Bretanha, na província de Rennes, em Arbrissel, próximo à orla oriental de Armórica, a poucas léguas de Anjou na França. Filho do padre e nobre Damalioch. Nesta época era caso banal o celibato entre os padres seculares, bem como estes pertencerem à nobreza. De tal sorte que Robert foi duplamente predestinado: nasceu nobre e herdeiro de uma paróquia.

Com a morte do pai, Robert sucedeu naturalmente no curato de Arbrissel, bem como deveria casar-se e gerar filhos, a quem deveria repassar seu curato. Segundo a tradição, as gerações de padres casavam e repassavam seus curatos como forma de assegurar a linhagem, a descendência da nobreza. Entretanto, Robert quebraria a tradição, pois pouco tempo depois abraçaria o celibato.

$\mathrm{Na}$ sua juventude Robert compartilha dos pecados comuns aos padres da época: a simonia (misturar dinheiro e religião) e o nicolaísmo (que vive nos pecados da carne). Segundo J. M. Bienven, "Robert incorreu em simonia em 1076, quando da eleição para sede episcopal de Sylvestre de La Guech" (Bienven, apud Dalarun; 1990, p. 16) para o bispado de Rennes. Robert ficaria sob a proteção deste por pouco tempo; ainda em 1076 o papa Gregório VII depõe o curioso bispo e Robert tem que fugir da Bretanha.

Saindo da Bretanha, Robert vai para Paris onde inicia seus estudos, tendo grande êxito. Ao regressar de Paris, este se tornaria no inimigo encarniçado dos pecados de simonia e nicolaismo. Os estudos em Paris fizeram de Robert um entusiasta pelas reformas morais propostas pelo papa Gregório VII. Não significa dizer que ele deixou completamente de pecar, sua própria condição de padre herdeiro natural já era um pecado. Em seu leito de morte este iria confessar: "Fui concebido nas iniqüidades, nutrido nos pecados e por minha culpa pequei de inúmeras maneiras" (André, apud Dalarun, 1990: p. 18). O que demonstra que mesmo na sua mais santa vida de padre celibatário "havia nele uma espécie de conflito interior, um estertor das entranhas que se pode considerar inumano e ímpio, nada podia remediá-lo [...]. Enquanto o acreditavam tranqüilo em meio à multidão, 0 mestre estava só, na mais completa angústia” (Baudri, apud Dalarun, 1990: p. 18).

Esta culpa originária que Robert carrega até seu leito de morte era um reflexo da moral cristã da época. Mesmo na mais elevada santidade, o homem medieval carregava a culpa do pecado original, relacionando-o principalmente ao pecado da carne, do sexo.

A conversão de Robert, ou melhor, sua adesão às reformas gregorianas seriam seguidas por outros, entre eles o bispo Sylvestre que seria reintegrado ao bispado de onde fora deposto. Robert une-se a este na luta pela moralização da cristandade. Contrariamente ao seu mestre, Robert agora era um homem culto. Sob a pro- 
teção de Sylvestre, a ação de Robert centraliza-se em libertar a Igreja da infame servidão dos leigos, levar ao extremo a noção de casamento, reprimindo as cópulas incestuosas dos padres e dos leigos, a condenação do concubinato entre os nobres e ainda impondo a abstinência sexual do clero. Em suma, Robert levantara a bandeira da reforma gregoriana, pela qual iria criar grandes inimigos.

Os choques entre reformadores e defensores da ordem antiga se daria, muitas vezes, de forma violenta. Em 1114, Pierra, bispo de Poitiers, seria exilado e preso pelo conde Guillaume de Poitou, por se opor e excomungar o mesmo, por concubinato, entre este e a viscondessa de Châtelleraut. Pierre morreu em 1115 devido aos maus tratos na prisão.

Os padres seculares não entendiam por que os monges e eremitas, entre eles Robert, que logo se tornaria um eremita, queriam impor aos demais clérigos uma regra que era deles, uma coisa que era boa para eles que viviam fora do mundo, "mortos - para - o- mundo", mas não para os "vivos", em todas as fibras da carne.

\section{3- A retirada para o deserto: o projeto de santidade}

Os conflitos aumentaram, e após a morte de Sylvestre, provavelmente em 1093, todo o ódio dos clérigos seculares se voltam para Robert, que se vê obrigado a deixar Rennes e vai para Angeres, no deserto. Não conseguindo comunicar sua vontade aos demais padres, a ida para o deserto é uma maneira de expiar os seus próprios pecados. Seria o começo de uma luta contra seus próprios desejos carnais. Começa por vestir-se em uma couraça de ferro, na qual ficaria por dois anos. A prática de vestimenta de ferro teria sido introduzida nas ordens religiosas por Domingos, discípulo de Pedro Damiano. Na mentalidade dos monges, a couraça seria um reforço à teoria platônica de que a alma estaria encarcerada na prisão do corpo; daí que ao aprisionar o corpo (o sexo), a alma ficaria mais livre, ou melhor, à vontade, a consciência. Seria uma forma de evitar o pecado, ainda que ele existisse na consciência. A tortura do corpo deixaria a mente em alerta. Por cima das placas de ferro, Robert usava vestes de eremita.

A vida de eremita no deserto é um grande momento da história de Robert, uma verdadeira reviravolta. A grande maioria dos santos da Igreja experimentaram a vida no deserto. Nele, o espirito, livre das frivolidades do mundo e convertido, só espera ser habitado em Deus.

A origem dessa tradição na Igreja provém do Oriente, onde a partir do século IV os anacoretas iam procurar Deus. Entre os mais famosos: Antão, Paulo de Tebas e Pacômio. "Como se carregassem dentro de si as saudades do martírio, doravante impossivel no império cristianizado. Vão sob sua própria autoridade ao encontro do insuportável" (Lacarrière, apud Dalarun, 1990, p. 24).

Para alguns historiadores, a crescente procura dos padres pelo deserto na virada do milênio se deve ao progresso das cidades no Ocidente: "As cidades geralmente não passavam de aldeias ampliadas. No entanto, a partir do século XI verifica-se em todo ocidente um inegável crescimento urbano, em decorrência da retomada do comércio" (Pastoureva, 1989, p. 39), o que caracteriza uma fuga do mundo. $O$ desprezo pelo mundo faz parte da mentalidade da Igreja ocidental, "esta 
profunda tendência, que nem todos conseguem realizar nas suas vidas, é encarada por alguns que se oferecem como exemplos e guias: os eremitas" (Le Goff, 1983, p. 229).

No ocidente o deserto é uma representação simbólica. $\mathrm{Na}$ verdade os eremitas se recolhem em montanhas ou planícies arborizadas. Assim, em 1095, Robert se refugia na floresta de Croan, no limite de Anjou e da Bretanha. "De resto, nesse tempo, o deserto era a floresta. Ali se refugiavam os adeptos voluntários ou involuntários da fuga ao mundo: eremitas, apaixonados, cavaleiros, bandidos, fora da lei, etc." (Le Goff, 1983a , p. 169-170).

Esta experiência de deserto ocidental seria chamado por muitos de "martírio verde", das mortificações e das penitências, verde como as folhagens da floresta.

Em seu deserto verde, Robert impõe a si mesmo tratamentos desumanos e extenua-se sob golpes cruéis, como: "usar um cilício de pêlos de porco, barbearse sem água, não conhecer outra cama além do chão, ignorar o vinho e os alimentos requintados ou gordurosos, entregar-se raramente a um curto sono", (Baudri, apud Dalarun, 1990: p. 29). E o conflito interior, o estertor das entranhas que levam Robert a comportar-se como um inimigo obstinado e injusto de si mesmo.

Outra caracteristica do deserto ocidental é que, além de verde, ele é populoso. Além dos homens comuns, filhos da terra, ele abriga muitos forasteiros, fugitivos do mundo. A floresta seria um rico celeiro de homens pecadores, mas também de muitos santos, como Bernard de Tiron, Yves de Chartres, Vital de Savigny e outros. Estes solitários e curiosos àscetas que, à margem da sociedade estabelecida, levaram uma vida campestre, mesclada de individualidade e convivência com outros.

Além do convivio com seus irmãos confrades, o eremita é homem de encontros, de pregações. O povo faz dos claustros lugar de visita e peregrinação, para pedir guarida e conselhos. Seu corpo depreciado passa a ter um poder mágico. 0 eremita é um santo em potencial.

No caso de Robert, além das virtudes de asceta, o povo vem também para ouvi-lo, pois é grande a sua fama de pregador. Abelardo, filósofo famoso pelo domínio da lógica e da eloqüência e que além de contemporâneo de Robert, era também da Bretanha, exalta o talento de seu conterrâneo na oratória.

Robert era um inflamado inimigo dos pecadores, "ele falava freqüentemente para inculcar terror no espírito dos pecadores, pois os que não observassem os mandamentos de Deus seriam lançados no abismo do inferno" (Baudri, apud Dalarun, 1990: p. 32). Mas por outro lado, era um pai dos arrependidos. "Nós o vimos invectivar os pecadores em seus sermões, mas ele consolava com afeto fraternal os que renunciavam ao pecado" (Baudri, apud Dalarun, 1990, p. 32).

Condenar os pecados e socorrer o pecador seria a marca pessoal de Robert.

Pela pregação, Robert conclama os outros à penitência.

\section{4 - A criação da Ordem de Fontevraud}

Com o tempo, Robert passa da condição de solitário a mestre, guia de uma multidão que o acompanha. $O$ povo vê nele a sua própria salvação. Sua responsabilidade aumenta, ele sabe que seu dever é alimentar este povo, é manter suas 
esperanças. Frente às estruturas econômicas feudais, Robert se vê obrigado a fundar uma comunidade religiosa, a Ordem de Fontevraud, que vai canalizar, ampliar e regulamentar a corrente de donativos e oferendas a ele destinadas.

A histónia da espiritualidade e a história da economia mais uma vez se interpenetram. Robert se via preso às circunstâncias, tentado a gozar dos favores da nobreza. O senhor Rensud de Craon faz a primeira doação: a terra de La Roe, onde seria instalada a primeira comunidade. Os integrantes da nova ordem religiosa não são monges, mas cônegos ou padres seculares. Robert adota para estes a antiga regra de Santo Agostinho: ascetismo, trabalho manual e despojamento que, vistos de outra forma, significavam aperfeiçoamento individual e serviço ao próximo.

A fama de pregador de Robert se espalha e, em 1096, o papa Urbano II, em passagem por Angers, por ocasião das Cruzadas, manda chamar Robert e o convida a fazer uma pregação diante dele na Igreja de Saint-Nicolas. Robert sai triunfante e é condecorado com o título de "Dei seminiverbum", ou seja, semeador do Verbo Divino. Urbano II ordena que Robert saia a pregar pelo mundo.

Com a criação da Ordem de Fontevraud surge mais um conflito na vida de Robert: se continuaria com sua comunidade ou se partiria pelo mundo como pregador, conforme ordenara o Papa. Robert decide partir, pois não vê sentido em continuar pregando para os já convertidos. Ao escolher a vida de intinerante, ele escolhe o modelo de Cristo como regra: parte "sem bordão e sem alforje", como os doze apóstolos de Cristo, "sem ter onde pousar a cabeça".

As peregrinações de Robert, principalmente sua radicalidade em imitar Cristo, seria motivo de grandes acusaçōes por parte de seus colegas bispos e abades dos episcopados por onde passava. E entre os motivos de que mais o acusavam estava sua autoflagelação e a presença de mulheres entre os seus conversos, motivo de escândalo para muitos.

\section{5 - As perseguições}

Marbode, bispo de Rennes, chega a acusá-lo de louco. "Um hábito abjeto sobre uma carne flagelada pelo cilício, um capuz esburacado, pernas seminuas, barba hirsuta, cabelos curtos sobre a testa, caminha descalço na multidão e oferece à assistência um incrivel espetáculo: dizem que só te falta um cetro de bobo para teres o aspecto de um louco" (Marbode, apud Dalarun, 1990: p. 42).

Para Marbode, Robert usurpou a ordem estabelecida. Seu vestuário, seus andrajos chocam a sociedade. Ele não é um monge, mas um padre ou cônego, por isso não podia usar vestes de monge. A moral cristã exige que cada ordem tenha sua veste própria, assim como na sociedade laica, cada ordem, casta, ou classe social tem a sua. Ao Rei a coroa, ao prelado sua mitra, ao leproso a sua rodela, etc. Robert estaria subvertendo a ordem natural da sociedade.

Além do mais, para Marbode, Robert exagerou em sua humildade, o que é um erro, pois segundo Aristóteles a virtude seria o equilíbrio entre dois vícios opostos - a discretia. Contra a radical humildade de Robert, Marbode diz que: "louvável não é andar sem vestes de linho, mas não dar valor às vestes de linho" (Marbode, apud Dalarun, 1990: p. 44). Para o bispo de Rennes, os andrajos de Robert eram um chamado à desordem. 
Outra preocupação de Marbode é que, ao pregar aos pobres, os "vulgares", Robert colocava estes contra os "dignitários", ou seja, as autoridades eclesiásticas e aristocratas. Ele vê um caráter político no discurso de Robert. Ao seguirem Robert, seus fiéis esvaziavam as paróquias, deste modo desestruturando as comunidades. Ao defender seus clérigos, Marbode defendia também a própria sustentação da ordem social na qual a Igreja estava assentada.

Mas o maior crime de Robert seria confundir os gêneros: misturar os sexos e as classes sociais. A sociedade feudal não podia admitir qualquer tentativa de nivelamento.

A mais grave infração de Robert seria sua relação com o sexo oposto. Para Marbode, Robert era um hipócrita que passava por abstinente aos olhos dos homens, mas se saciava secretamente com a came e o vinho: "viver numa continência criminosa e numa santidade infame é pior que o concubinato" (Marbode, apud Dalarun, 1990: p. 50) que ele próprio tanto condenava.

Marbode, assim como Robert, era celibatário e não entendia como este pudesse viver em meio às mulheres sem cair em tentação, pois mesmo longe delas não conseguia vencer os apetites da carne. Para ele, Robert procurava a sua própria condenação: ele, pelo contrário, procurava se afastar delas.

Robert sentia o mesmo desejo carnal pelas mulheres, mas conviver com elas fazia parte de seu projeto de santidade.

\section{6 - As mulheres como projeto de santidade}

Percebemos a mentalidade da Igreja para com as mulheres nas palavras e atitudes dos santos. São Nilo, por exemplo, pouco antes de morrer nega-se a receber a visita de uma princesa que o venerava como santo, "porque - dizia - se eu vir uma mulher, voltará o demônio imediatamente a atormentar-me" (Fluery, apud Lins, 1958: p. 111). Outros, na mesma linha, chegaram a condenar radicalmente o convívio com as mulheres, ainda que estas fossem da sua própria família. " $\mathrm{E}$ assim, nenhum se atreva a dar ósculo à viúva, nem donzela, nem a mulher alguma, ainda mui chegada em parentesco, como mãe, irmã ou tia" (Ferreira, apud Lins, 1958, p. 112). São Jerônimo, entre outros, sustentava a tese de que "o contato da mulher é como se fosse infeccioso e envenenado para o homem, devendo ser evitado tanto quanto a mordedura de um cão danado" (Bayle, apud Lins, 1958, p. 111).

Muitos ascetas haviam encontrado formas de exorcizar e testar sua força frente aos desejos da carne. Uns se açoitavam, jogavam-se em meio às urtigas ou os espinhos, outros, considerando o desejo sexual como um fogo, uma chama, opõem a brasa à brasa. Era comum naquela época o famoso "duelo judiciário", onde os acusados da quebra do celibato podiam provar sua inocência ou superação dos desejos carnais com a prova do fogo, ou seja, pegando publicamente em brasa ou metais colocados ao fogo. Se não se queimassem significaria que estavam imunes dos desejos, que o fogo fora vencido pelo fogo.

Robert segue a tradição da prova do fogo pelo fogo, só que ao invés de pegar em fogo ele coloca como prova de fogo conviver com as mulheres e resistir às tentações. Seria o confronto do corpo com o corpo. Suportar o desejo convivendo 
com as mulheres fazia parte de seu projeto de santidade. "O pio fundador de Fontevraud, d'Arbrissel, foi acusado, no alvorecer do século XI, de deitar-se com as religiosas mais belas de seu convento, por tentação violenta, mais meritória sua castidade" (Bayle, apud Lins, 1958, p. 189).

\section{7- As regras na Ordem de Fontevraud}

A vida nos primeiros tempos da comunidade de Fontevraud é de simplicidade. "Cabanas miseráveis mal protegem das intempéries; um simples oratório para se rezar a Deus [...]. A humildade é a regra: o grupo se adorna com o belo nome de "Pauperes Christi", os pobres de Cristo [...]. Seu chefe, declinando dos titulos de abade, não quer ser chamado senão de mestre" (André, apud Dalarun, 1990, p. 58).

Diante das pressões externas, por volta de 1101, Robert resolve pôr ordem na sua comunidade. Estabelece lugares distintos entre as celas dos homens e das mulheres e distribui atividades diferentes entre seus membros. As mulheres seriam consagradas à clausura e os homens aos trabalhos manuais. Os padres celebravam as missas, o irmão leigo sujeitava-se ao trabalho. A ordem, tão cobrada por Marbode, seria mantida, e o poder sacerdotal junto aos sacramentos também seria mantido.

Apesar das reformas o perigo continuava. As mulheres, apesar de isoladas, estavam próximas dos homens. As críticas centralizam-se cada vez mais neste ponto. Geoffroy, abade de Vendôme, classifica a atitude de Robert como um sacrilégio: "Crucifica-te no leito delas por um novo martírio" (Geoffroy, apud Dalarun, 1990, p. 61).

Além de separar homens e mulheres, Robert cria uma divisão entre as mulheres, a qual seria motivo de muitas críticas. Um claustro vai ser dedicado à Virgem Maria, no qual seriam recolhidas as virgens e damas viúvas da aristocracia que para lá fluiam. Em outro, dedicado a Madalena, seriam acolhidas as prostitutas. Como se vê, a divisão entre pecadoras e não-pecadoras era, artes de mais nada, uma divisão de classes sociais.

Entre as mulheres do claustro da Virgem Maria, Robert escolhe duas para ocupar cargo de destaque: Hersende e Pétronille, uma como prioresa e outra como vice. Ambas de linhagem aristocrata. Hersende era filha de Hubert I da Champagne, viúva de Guillaume, conde de Montesoreau. Pétronille fora casada com Ouri, o Ruivo, senhor de Chemillé. Daí para frente, a Ordem de Fontevraud seria abrigo de muitas outras damas e donzelas da aristocracia: donzelas confiadas à ordem por pais que não queriam dividir seus bens em dotes; mulheres banidas de seus maridos, viúvas e mulheres conversas que deixavam seus maridos vendo-se traídas.

A Ordem de Fontevraud crescia à medida em que a Igreja intensificava sua moral reformadora. Com a regulamentação do casamento entre os nobres, a proibição do concubinato e a exigência do celibato ao clero, esta ordem passa a abrigar as mulheres marginalizadas pela nova ordem social.

Outro motivo que muito contribuiu para a procura da Ordem de Fontevraud por mulheres da nobreza foram as Cruzadas. Ao perderem seus maridos nas 
"guerras santas", muitas procuram abrigo junto a Robert, outras ficam à frente dos negócios do marido. Desta forma, as Cruzadas contribuiriam para a ascensão das mulheres à aristocracia.

Apesar de ter confiado o priorado de sua ordem a duas damas viúvas oriundas da classe aristocrata, Robert tinha um grande carinho para com as prostitutas. Ele as chamava de "minhas filhas". Andava pelas cidades condenando seus pecados e prometendo-lhes misericórdia. Recolhia consigo aquelas que se diziam arrependidas.

O culto a Madalena é parte essencial do movimento eremítico de Robert. Madalena foi a que mais de perto tocou e abraçou o Cristo. Assim como Cristo, ele traz o perdão às pecadoras, em seguida arrasta-as para o deserto. $O$ deserto de Madalena não é uma masmorra para expiação, mas o espaço do arrebatamento para Cristo. O fundador de Fontevraud está preocupado em "extirpar o crime e não o criminoso" (Geoffroy, apud Dalarun, 1990, p. 61).

Um episódio curioso marca a preocupação de Robert para com a salvação da mulher. Em suas andanças, por volta de 1114, Robert aproxima-se de Menat, onde enfrenta uma tradição antiga de que as mulheres eram proibidas de entrar na igreja, entretanto, recebiam a comunhão fora da mesma. Segundo esta tradição, as mulheres que ousassem e entrassem na igreja, recebiam o castigo de São Menelau: sairiam mutiladas. Ao se aproximar da igreja, por ocasião da santa missa, Robert interroga a todos: "Oual o mais importante, o templo material de Deus, ou o templo espiritual onde Deus habita? Se a mulher toma e come o corpo e o sangue de Cristo fora da Igreja, imaginai, a loucura não será acreditar que não deve entrar na igreja!" (Geoffroy, apud Dalarun, 1990, p. 116). O discurso de Robert convence as mulheres, estas entram na igreja e nada acontece. A partir dai a tradição é desfeita.

Diferente da maioria dos clérigos reformadores, que buscarn na imagem da Virgem Maria o modelo de mulher, rebaixando a mulher terrestre à condição de Eva, Robert, pelo contrário, vai buscar em Madalena, a pecadora mas arrependida, o modelo de salvação. Robert acredita que a salvação veio ao mundo pela mulher, foi nela que tomou corpo. Portanto, o corpo da mulher é lugar de perdição, mas, também, de salvação.

\section{8 - A preparação para a morte}

Os anos se passaram e em 1116 encontrava-se enfermo em seu leito de morte. Ele sente que sua hora se aproxima. Nesta época, a mentalidade do homem perante a morte era de que esta era uma representação, ou antecipação do Juízo Final. O moribundo devia dispor sabiamente de seus poderes e de seus bens, caso o Céu o tenha cumulado dos mesmos com vista à salvação de sua alma e ao interesse dos que sobrevivem. A herança de Robert, ou da Ordem de Fontevraud é grande: terras, bosques, vinhas, moinhos e cerca de 20 priorados espalhados por todo o oeste da França. Robert precisa prestar contas aos seus e a Deus.

Antes, Robert já havia confiado os priorados da ordem a duas mulheres: Hersende e Pétronille, tendo a primeira morrido recentemente. Agora Robert estava preocupado com o destino da Ordem após sua morte. De seu leito de morte, con- 
voca seus confrades e pede-lhes que renovem seus votos de submissão às mulheres. $\mathrm{E}$ assim os interroga: "Perguntai a vós mesmos, enquanto estou vivo, se quereis perseverar em vosso projeto, ou seja, para a salvação de vossas almas, obedecendo às servas de Cristo. Pois sabeis que tudo quanto edifiquei em toda parte com a ajuda de Deus, eu o submeti ao seu poder e a seu domínio. Mas, se não quiserdes mais ficar com elas como o empreendestes, dou-vos a liberdade, porém com o meu conselho, de escolher uma outra ordem" (André, apud Dalarun, 1990, p. 122).

Em outra oportunidade, diante dos bispos das dioceses vizinhas que vieram visitá-lo, Robert declara: "Sabeis, caríssimos, que tudo o que edifiquei no mundo foi feito para o bem das freiras [...]. E, o mais, tanto eu como meus discípulos, para salvação de nossas almas, nos submetemos às suas ordens" (André, apud Dalarun, 1990, p. 123).

Com a morte de Hersende, primeira prioresa, Robert preocupa-se em escolher a futura e primeira abadessa. Segundo a tradição, as abadessas sempre eram escolhidas entre as freiras virgens, entretanto Robert quebra a tradição e escolhe Pétronille, viúva e oriunda da nobreza. Robert reservava uma certa preferência para com as viúvas, mulheres experientes, capazes de continuar seu trabalho. A este respeito, Regine Pernoud nos informa que "este mosteiro duplo foi colocado sob a autoridade, não de um abade, mas de uma abadessa. Esta, por vontade do fundador, deveria ser viúva, tendo tido a experiência do casamento. Para completar, digamos que a primeira abadessa que presidiu os destinos da Ordem de Fontevraud, Pétronille de Chemillé, tinha 22 anos quando foi escolhida" (Pernoud, 1994, p. 112).

Ao confirmar o nome de Pétronille, Robert a aconselha; "O espírito do orgulho é um mal, mas as falsas aparências da humildade são piores. $O$ espírito da vanglória é um mal, mas as falsas aparências da santidade são piores. $O$ espírito de inveja é um mal, mas as falsas aparências da caridade são piores. O espirito da cupidez é um mal, mas as falsas aparências da misericórdia são piores. O espírito da glutonaria é um mal, mas as falsas aparências de abstinência são piores. $\mathrm{O}$ espirito de luxúria é um mal, mas as falsas aparências de castidade são piores. Contra todos esses males ouvidos ou conhecidos, manifestos ou dissimulados, cautela-te, serva de Cristo! Pois a virtude é um justo meio-termo entre vícios opostos. Cuidado para nada fazeres em excesso! Tudo o que é excessivo transforma-se em vício" (André, apud Dalarun, 1990, p. 91). Parece que Robert havia incorporado os conselhos de Marbode.

Ao justificar sua escolha de uma viúva e não uma donzela, Robert nos diz: "Persisto, é claro, em aspirar a Maria nos céus, mas escolhi Marta, que sabe administrar com desvelo os assuntos temporais' (André, apud Dalarun, 1990, p. 125).

Robert nunca perdera sua concepcão de mulher como símbolo do pecado. Portanto, ao pé da letra, as mulheres eram indignas do patronato de Maria, e sua escolha para liderar a ordem remontam de sua indignidade. "Vencedor da ordália sexual, Robert buscou na própria escolha de regulamentação de sua ordem um prolongamento de sua penitência, uma derradeira provação, expiatória de sua falta primeira" (André, apud Dalarun, 1990, p. 128). Portanto, longe de ser uma forma de 
emancipação das mulheres, Robert fazia destas uma lenta ascensão dos degraus de humildade que o levaria a Deus. "Fontevraud, mosteiro majoritariamente feminino, é concebido antes de tudo para a salvação dos irmãos: é com esse objetivo que o fundador diz tê-los submetido às ordens de suas irmãs. Serviço degradante, pois nada mais humilhante que obedecer a um superior que, secretamente, consideramos indigno de sua posição" (André, apud Dalarun, 1990, p. 128-129).

A morte de Robert se aproxima e seus admiradores traçam-lhe um retrato de santo controverso. De um lado, o santo promotor de perturbações sociais e escândalos; de outro, o santo sábio, cujo magistério era incontestável; homem pacífico, mediador das discórdias, repressor dos pecados e amigo dos pecadores.

\section{9 - A morte do santo}

A saúde de Robert se agrava, ele se encontra em Orsan, longe de Fontevraud, e lamenta por isto: "Fontevraud, o Fontevraud, como sonhei jazer em ti!" (André, apud Dalarun, 1990, p. 137).

Nesta época, crescia na Idade Média o culto às relíquias, à adoração aos corpos dos santos. André, um dos seus confrades, vendo em Robert um potencial de relíquia, pede-lhe que ordene que, após sua morte, seu corpo seja levado para Fontevraud.

Robert, diante do pedido de André, perante seus irmãos, irmãs e do bispo de Bourges, Léger, suplica: "Não quero ser inumado fora de Fontevraud. Pois bem sabes, meu pai, que constituí Fontevraud sede de todos os lugares. É lá que está a maior parte da nossa congregação, assim como o fundamento da nossa religião. Não te peço para inumar-me no mosteiro ou no claustro, mas somente entre os pequenos irmãos, na lama de Fontevraud [...]" (André, apud Dalarun, 1990, p. 140141).

Antes de um desejo pessoal, Robert vê nisto uma necessidade interna à congregação "que a unidade seja selada para sempre sobre seu corpo, [...]. Melhor do que os estatutos, melhor que a coação, o santo corpo selado em Fontevraud lembrará a todos seu bizarro compromisso para que, em torno dele o viço da Criação se ordene em perfeita cosmogonia" (André, apud Dalarun, 1990, p. 142-143).

Robert tinha plena consciência de sua importância para a Ordem, e mais do que isto, que logo o reconheceriam como santo. O momento da morte se aproxima e Robert sente a necessidade de prestar contas a Deus; quanto aos seus na terra, já tinha tomado todas as providências, daí pede o "lenho da cruz" e diante da santa cruz e dos presentes se acusa: "Escutai, Céu e Terra! O Filho de Deus veio ao mundo para salvar os pecadores, dos quais sou o primeiro. Pois fui concebido na iniqüidade, nutrido nos pecados e, por minha culpa, pequei de muitas maneiras" (André, apud Dalarun, 1990, p. 147).

Com esta cerimônia de confissão, Robert entrega-se a Deus para ser julgado. Nesta época, na Idade Média, acreditava-se que a morte era uma representação do Juizo Final, onde o moribundo apresentava-se a Deus com o seu livro de contas individual, livro este "que os ressuscitados levavam-no pendurado no pescoço, como um documento de identidade, ou então como um balanço de contas a apresentar às portas da eternidade" (Ariès, 1989, p. 33). 
Para os medievais, os murmúrios agonizantes do moribundo eram interpretados como uma luta do bem contra o mal, que disputavam a posse do mesmo. "Seres sobrenaturais invadem o quarto e aglomeram-se junto da cabeça do doente. De um lado, a Trindade, a Virgem, toda a corte celestial; do outro, Satanás e exército de demônios [...]. Esta prova consiste numa derradeira tentação: o moribundo verá a sua vida toda, tal como está contida no livro, e será tentado, quer pelo desprezo de suas faltas, quer pela vã glória de suas boas ações. Deus e sua corte estão presentes para verificar como o moribundo vai se comportar na última prova que lhe proporcionará a eternidade" (Ariès, 1989, p. 34).

A morte demora; enquanto isto Robert recebe a última tentação. As forças do mal o atacam e ele agoniza e delira. Decerto, diz ele: "Pensavam que eu devia morrer como uma besta e por isso, em vão, vieram tentar espreitar-me e enganarme. Porque, queiram ou não, com a ajuda de Deus, hei de morrer como um bom cristão" (André, apud Dalarun, 1990, p. 148).

\section{0 - A luta pelo corpo do santo: uma relíquia de grande valor atrativo}

Robert morreu em 25 de fevereiro de 1116. Os religiosos vestiram seu corpo num cilício e um grosseiro burel de eremita, conforme ele usava em vida. $O$ espírito de Robert repousava em paz, mas seu corpo não.

Momentos antes de sua morte, Robert havia manifestado seu desejo de ser enterrado em Fontevraud, junto aos seus irmãos e irmãs, mas não foi tão fácil para seus confrades realizarem seu desejo.

A crescente devoção e adoração aos santos como relíquias seria motivo de grande disputa pelo corpo de Robert. Não só os irmãos confrades e freiras, mas as demais autoridades eclesiásticas da região da Bretanha tinham consciência da importância do corpo do santo. Cada um queria enterrar o corpo do santo em sua cidade, diocese ou convento, pois, com isto, este passaria a ser local de romaria e peregrinação. $\mathrm{O}$ corpo do santo seria um excelente atrativo e um grande motivo de crescimento para a região, tanto do ponto de vista religioso, como econômico, com o crescimento do fluxo de fiéis por ocasião das visitas e peregrinações.

Mesmo antes de Robert morrer as disputas começaram. Léger, bispo da diocese em que Robert se encontrava, já havia demonstrado interesse pelo corpo do santo; mesmo estando presente no momento em que este confessou seu desejo de ser inumado em Fontevraud, queria enterrá-lo em Berri, sede da diocese.

Percebendo o perigo, logo após sua morte, irmãos e irmãs levam o corpo do santo para o claustro das irmãs e ali entrincheiram-se. Mas os homens de Léger avançam sobre estes, arrombam as portas, roubam o corpo, transportam para Berri e depositam na capela da igreja central. Para Léger, "Deus tinha decorado sua diocese com tal e tão santa personagem que, acreditavam, intercederia por eles no paraiso" (André, apud Dalarun, 1990, p. 156). Por isso, este deveria ser enterrado ali, pois se "Deus quisesse que ele fosse enterrado na dita Fontevraud não teria permitido que em sua região falecesse" (André, apud Dalarun, 1990, p. 157).

Pétronille, suas irmãs e irmãos vão a Berri e armam protesto diante do corpo do santo: prometem não comer, nem beber até obter a liberação do corpo e en- 
terrá-lo em Fontevraud, conforme ele havia pedido. E mais do que isso, Pétronille ameaça apelar até para Roma se for preciso.

Depois de muita confusão, após quatro dias de jejum as irmãs e irmãos recebem o bispo Léger que diante de todos declara-se vencido, e diz: "Tudo que fiz foi pelo amor que sentia por ele; e eu desejava que ele fosse enterrado aqui a fim de ser posto a seus pés" (André, apud Dalarun, 1990, p. 159). Robert seria, finalmente, transportado para Fontevraud. Em contrapartida, deixaram, como consolação, para o bispo, o coração de Robert, o qual seria enterrado na igreja de Berri. Ao falecer, em 1120, Léger seria enterrado ao lado do coração de Robert e sobre o mausoléu seria escrito: "Tal foi o amor por Robert durante sua vida que não quis, depois de morto separar-se do seu coração" (André, apud Dalarun, 1990, p. 160).

Chegando a Fontevraud, irmãos e irmãs prepararam-se para inumar Robert no lugar onde havia designado: na lama. Mas, teriam de enfrentar mais uma batalha. Os bispos e nobres da região achavam que deveria ser enterrado na grande igreja, com todas as honras. Para estes, as palavras de Robert não deviam ser entendidas ao pé da letra, mas como metáfora. A lama significava o humus, humilitas ou humildade de Robert.

Cansados de combater, as freiras e confrades não resistiram, e assim, Robert seria enterrado, com todas as honras, na igreja de Fontevraud. Os irmãos e irmãs, surpresos, vêem seu mestre ser enterrado com grande pompa e honras no dia 7 de março de 1116.

Segundo Jacques Dalarun, o gesto dos bispos e nobres, "aparentemente desejosos de homenagear o defunto, mas preocupados, sem dúvida, em defender a posição das mulheres de seu sangue, de seu mundo" (Dalarun, 1990, p. 161-162).

\section{1 - O processo de canonização: um projeto fracassado}

Na Idade Média, o processo de canonização era algo simples. André Vauchez nos diz que "no século XII ainda não existe processo regular de canonização, e a santidade se sucede, pois, facilmente; algumas sevícias suportadas, salteadores que se prosternaram, uma morte exemplar e o assunto está resolvido" (Vauchez, apud Dalarun, 1990, p. 144).

Para a Ordem de Fontevraud, Robert seria tranqüilamente canonizado como santo. Entretanto, a coisa não foi tão fácil, e além de não ser canonizado, Robert seria esquecido e calado pela própria Ordem.

O primeiro passo rumo à canonização de Robert seria escrever sua vida, o que na época chamavam de "Vita Santa". Para tanto, Pétronille, num primeiro momento, contrata Baudri de Bourgueil, um padre poeta de grande prestígio literário na época.

Ao término de seu trabalho, Pétronille viu-se traída, pois, sua "Vita Prima" é muito pouco amena para com a abadessas: logo de saída, com uma insistência descortês, o autor lembra que Pétronille passou por leitos nupciais. Gaba os méritos de Hersende e explica que só a morte a impediu de ocupar o cargo de abadessa" (Dalarun, 1990, p. 167).

Desgostosa da primeira narrativa, Pétronille encomenda uma outra "Vita" ao prior de Saint-Jean-de-1'Habait, o padre André, pois este, além de ter vivido os 
passos de Robert, sendo considerado o discipulo querido, vivia fielmente a tradição na mais digna submissão. A segunda narrativa seria dedicada à glória de Robert e da abedessa.

Os escritos de André seriam censurados por sua declarada bajulação à abadessa, o que fez Pétronille fazer, ou mandar fazer, uma revisão aos escritos deste, o que complicaria mais ainda o processo, pois além de suspeito, o conteúdo estaria rasurado.

O certo é que, as duas "Vitas", ambas suspeitas, dificultariam o processo de canonização, que oficialmente só seria iniciado a partir do século XVII.

Aos poucos, o esquecimento é cuidadosamente organizado; nenhuma história, nem do antes, nem do após-morte. "Cumulado de uma honra que não desejava, escondido pelas. religiosas na parte mais secreta de seus quartéis, Robert é subtraído aos irmãos e às multidões. Proibido a seus companheiros, inacessivel à piedade popular. Seu túmulo não vê florescer qualquer milagre, o rumor de santidade diminui e se extingue. Sobre o mausoléu de pedra, o esquecimento torna a fechar-se" (Dalarun, 1990, p. 166).

Assim, misteriosamente, as irmãs calam o seu santo, não deixam crescer sobre ele nenhum entusiasmo.

Uma outra tentativa de canonização viria no século XIX, porém não menos infrutífera. Robert seria considerado um caso encerrado.

Robert seria um santo popular, mas nunca canonizado.

Apesar de não ter sido sequer beatificado, a Igreja Católica o homenageia, em seu "Santo para cada dia", como beato, em 25 de fevereiro, dia do aniversário de sua morte.

\section{Referências bibliográficas}

ARIÉS, Philippe. Sobre a história da morte no Ocidente desde a Idade Média. Trad. Pedro Jordão. Lisboa: 1989.

DALARUN, Jacques. Amor e celibato na Igreja Medieval. Trad. Antonio de P. Danesi. São Paulo: Martins Fontes, 1990.

DUBY, George. A Europa na Idade Média. Trad. Maria Assunção Santos. Lisboa: Teorema, 1989.

- O cavaleiro, a mulher e o padre. Trad. G. Cascais Franco. Lisboa: Dom Quixote, 1988.

LE GOFF, Jacques. A civilização do Ocidente Medieval. Trad. Manuel Ruas. Lisboa: Editorial Estampa, 1983. v. 1.

- . (org.). O homem medieval. Trad. Maria Jorge Vilar de Figueiredo. Lisboa: Presença 1989.

LOYN, H. R. (org.). Dicionário da Idade Media. Trad. Álvaro Cabral. Rio de Janeiro: Zahar, 1991.

NASCIMENTO, Carlos Artur. Filosofia Medieval. São Paulo: Brasiliense, 1992 (Coleção Primeiros Passos).

LINS, Ivan. Idade Média: A cavalaria e as Cruzadas. $3^{\mathrm{a}}$ ed. Rio de Janeiro: Livrania São José, 1958.

PERNOUD, Jacques. Idade Média: o que não nos ensinaram. $2^{\mathrm{a}}$ ed. Trad. Maurício Brett Menezes. Rio de Janeiro: Agir, 1994.

PATOUREVA, Miguel. No tempo dos Cavaleiros da Távola Redonda. Trad. Paulo Neves. São Paulo: Companhia das Letras, 1989.

RICHARDS, Jeffrey. Sexo, desvio e danação: as minorias na Idade Média. Trad. Marco Antonio E. Rocha e Renato Aguiar. Rio de Janeiro: Zahar, 1993.

ROPS, Daniel. Histónia da Igreja de Cristo: a Igreja das Catedrais e das Cruzadas. Trad. Eduardo Pinheiro. Porto: Tavares Martins, 1961. Tomo III.

THURSTON, Hebert J.; ATTWATER, Donald (orgs.). Vida dos santos de Butter. trad. Hamilton Francischetti. Petrópolis: Vozes, 1985, v. II. 